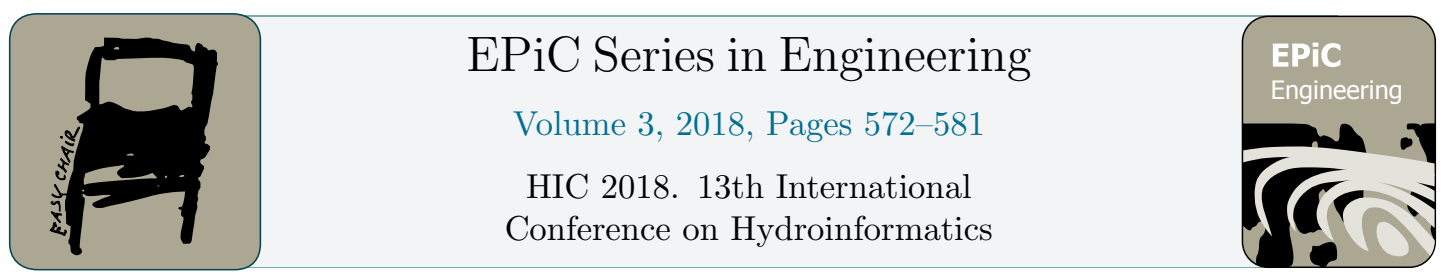

\title{
On-line Measuring Sensors for Smart Water Network Monitoring
}

Armando Di Nardo ${ }^{1,4,8,11}$, David Baquero González ${ }^{22}$, Tom Baur ${ }^{1}$, Romeo Bernini $^{1,14}$, Sergio Bodini ${ }^{1,19}$, Sante Capasso ${ }^{1,8}$, Furio Cascetta ${ }^{1,4}$, Francesca Castaldo $^{17}$, Michele Cocco ${ }^{1,7}$, Philippe Cousin ${ }^{1,23}$, Mario D'Acunto ${ }^{1,25}$, Romeo Di Leo ${ }^{16}$, Bartolomeo Della Ventura ${ }^{6,16}$, Anna Di Mauro ${ }^{1,4,11^{*}}$, Michele Di Natale $^{1,4}$, Guido Di Virgilio ${ }^{1,29}$, Marco Doveri ${ }^{1,13}$, Bouabid El Mansouri ${ }^{1,10}$, Roberto Germano $^{17}$, Carlo Giudicianni ${ }^{1,4}$, Nicolas Giunta ${ }^{1,23}$, Roberto Greco ${ }^{1,4}$, Pasquale Iovino $^{1,8}$, Evina Katsou ${ }^{26}$, Ralf Koenig ${ }^{1,9}$, Chrysi S. Laspidou, ${ }^{1,3}$, Vincenzo Lisbino ${ }^{17}$, Lisa Lupi ${ }^{1,7}$, Eva Martínez Díaz ${ }^{1,5}$, Dino Musmarra ${ }^{1,4,8}$,

Montse Mussons Olivella ${ }^{22}$, Osvaldo Paleari ${ }^{1,18}$, Jordi Raich ${ }^{28}$, Fiona Regan $^{1,24}$, Manuel J. Rodriguez-Pinzon ${ }^{27}$, José Manuel Rodriguez-Varela ${ }^{1,12}$, Luca Sanfilippo, ${ }^{1,19}$, Jai S. Seelam ${ }^{1,20}$, Giovanni Francesco Santonastaso ${ }^{1,4,11}$, Dragan Savic ${ }^{1,2}$, Andrea Scozzari ${ }^{1,15}$, Francesco Soldovieri ${ }^{1,14}$, Francesco

Paolo Tuccinardi ${ }^{1,17}$, Velitchko G. Tzatchkov ${ }^{1,12}$, Lydia S. VamvakeridouLyroudia $^{1,2}$, Martin Van Rijn ${ }^{1,21}$, Raffaele Velotta ${ }^{1,6}$, Salvatore Venticinque ${ }^{1,5}$, J. W. Wouters ${ }^{1,20}$

${ }^{1}$ EIP Action Group Ctrl+SWAN, Aversa, IT

${ }^{2}$ University of Exeter, Exeter, U.K.

${ }^{3}$ University of Thessaly, Volos, GR

${ }^{4}$ Università della Campania "L.Vanvitelli", Aversa, IT

${ }^{5}$ FCC AQUALIA, Madrid, ES

${ }^{6}$ University of Naples "Federico II", Napoli, IT

${ }^{7}$ EdgeLab srl, La Spezia, IT

${ }^{8}$ Environmental Technologies srl spin-off company, Caserta, IT

${ }^{9}$ HACH LANGE GmbH, Duesseldorf, DE

${ }^{10}$ IbnTofail University, Kénitra, MAX

${ }^{11}$ Med.Hydro srl academic spinoff, Aversa, IT

${ }^{12}$ Mexican Institute of Water Technology, Jiutepec, MEX

${ }^{13}$ National Research Council of Italy (CNR-IGG), Pisa, IT

${ }^{14}$ National Research Council of Italy (CNR-IREA), Napoli, IT

${ }^{15}$ National Research Council of Italy (CNR-ISTI), Pisa, IT

${ }^{16}$ University of Naples "Federico II", Napoli, IT

${ }^{17}$ Promete Srl - CNR spin-off company, Napoli, IT 


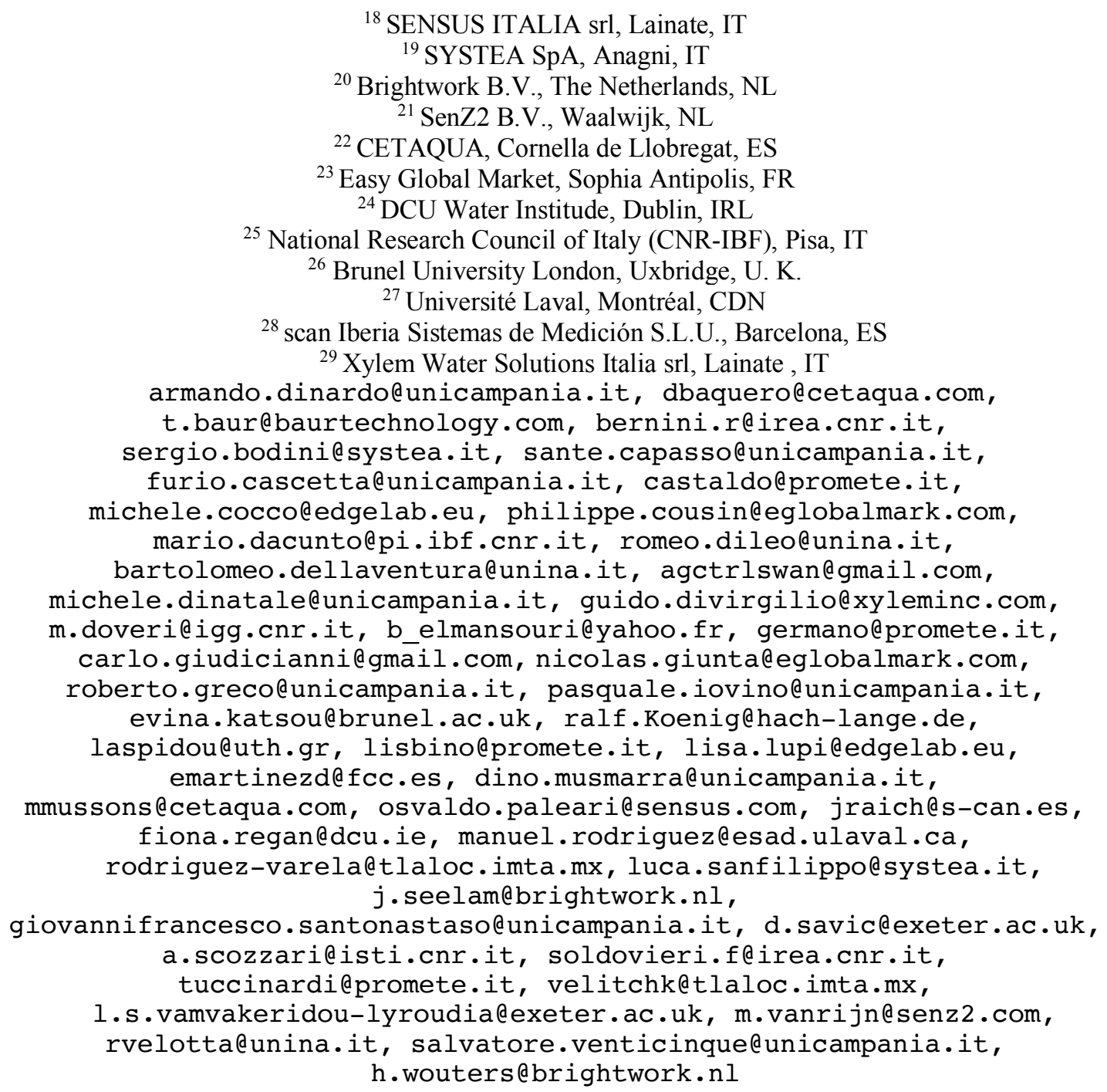

\begin{abstract}
Smart cities are getting essential to drive economic growth, increase social prospects and improve high-quality lifestyle for citizens. To meet the goal of smart cities, Information and Communications Technology (ICT) have a key role. The application of smart solutions will allow the cities to use ICT and big data to improve infrastructure and services (i.e. network efficiency, protection from contamination, etc.). In the water sector, the integration of smart meters and sensors coupled with cloud computing and the paradigm of "divide and conquer" introduces a novel and smart management of the water network allowing an efficient online monitoring and transforming the traditional water networks into modern Smart WAter Networks (SWAN). The Ctrl+SWAN (Cloud Technologies \& ReaL time monitoring+Smart WAter Network) Action Group (AG) was created within the European Innovation Partnership on Water, in order to promote
\end{abstract}


innovation in the water sector by advancing existing smart solutions. The paper presents an update of a previous work on the state of the art on the best On-line Measuring Sensors (OMS) already available on the market and innovative technologies in the Research and Development (R\&D) phases.

\section{Introduction}

The impact of Information and Communication Technologies (ICT) has become essential in the water management sectors. In fact, the integration and implementation of new ICT devices for monitoring and control the existing Water Systems (WSs) (drinking, distribution, sea, river water, etc.) represents one of the most challenging tasks for technology and water experts. The integration of innovative on-line sensors in the WSs can contribute to monitor and control many water quantitative (e.g. flow, pressure, etc.) and quality (e.g. residual chlorine, $\mathrm{pH}$, organic matter, turbidity, disinfection by-products, etc.) parameters providing smart water management solutions for the measurement, automation, control, protection and on-line monitoring. On-line Monitoring Sensors (OMS) contribute to realize the notion of Smart Water Networks (SWANs) as subsystem of the Smart City, a novel paradigm recently recognized by the scientific and technical international community $[1,2,3,4]$.

The European Innovation Partnership (EIP) on water activated a specific Action Group (AG), titled Ctrl+SWAN (Cloud Technologies \& ReaL time monitoring+Smart WAter Network) - made up from about one hundred universities, research centers, water utilities, start-ups and large companies in order to promote innovation in the water sector by advancing existing smart solutions based on the potentiality of on-line monitoring systems. Ctrl+SWAN aims to the further development of innovative sensor systems' to be integrated in the design of an innovative approach to the water networks management, in order to enhance the implementation of smart solutions into SWANs.

In particular, the AG aims to disseminate in the World of Water, the advantages to use new on-line sensors and to develop, together with its members, novel applications as effective monitoring (water quantity and quality monitoring, early warning systems, etc.), optimal partitioning (real time management of the optimal district meter areas (DMAs) and dynamic control (real time flow and pressure management), but also serious gaming and water re-use (i.e., dual networks). The key idea of the Action Group Ctrl+SWAN is based on the innovative on-line sensors that can overcome the traditional management of water networks and to face the important issues such as the reduction of water losses, the analysis of big data, the reduction of water demand, the protection of water quality, the users' awareness, etc.

A very important application of OMS is water quality protection, crucial in an extraordinary period of inauspicious terroristic attacks $[5,6]$, but ordinarily useful to guarantee a high quality and safe of delivered drinking water.

In this technological application context, the integration of smart meters, sensor and biosensors allows to monitor and control WS like never before. On one side, the On-line Monitoring Sensors allows to elaborate early warning systems for a timely detection of problems, as reported in [6], but, on the other side, it is also possible by on-line control devices, to improve decision-making by activating quickly and effective protection actions [6] to mitigate significantly the negative effect of accidental or intentional water contamination.

The paper is focused on water quality sensors with specific reference to the main innovative technologies developed by the members of the Action Group Ctrl+SWAN.

Specifically, during recent years, different OMS, at research level, prototype scale or already in the market, have been developed to monitor water quality [7]. 
At commercial scale, several on-line sensors, based on different technologies [8], are available on the market and, even if they will not represent an exhaustive list, these OMS produced by Ctrl+SWAN members and partners are reported in the following:

- monoparametric water analyzers, automating a specific analytical method for water analysis as Micromac 1000 base (Systea);

- multiparametric water analyzer: normally based on automated multiple methods covering part of the contamination spectrum like Micromac C MP and Easychem on-line (Systea);

- spectrometer based: on-line spectrometer as Spectro::lyserTM and in-pipe LED-based spectrometer as i::scan (S::CAN) [7];

- lab on-chip sensor technology as EventLab (Optiqua) [9];

- biological sensors as TOX control (Microlan) or Easychem TOX Early Warning (Systea);

- Radio-Frequency IDentification (RFID) based on smart monitoring and control technology (Sand-Cycle) for moving bed bioreactors (Brightwork);

- sensors for the measurement of UV-absorbance, as organic matter content, and trihalomethanes (the main chlorinated disinfection by-product) (S-Can, Realtech, Multisensor MS2000, distrubted by Avensys Solutions);

- digital optical UV spectral sensors as NitraVis 700 and NiCaVis 700 and optical SAC and UVT sensor as UV 701 IQ SAC (WTM Xylem group);

- digital ion selective (ISE) combination sensor as Varyon plus 700 IQ (WTM Xylem group).

Further, at prototype scale, the members of the Action Group Ctrl+SWAN are working on different water quality sensor technologies. In the following, even if in a not exhaustive list, the main OMS under development by Ctrl+SWAN members are reported:

- piezoelectric sensors based on the Quartz-Crystal Microbalance (Novaetech srl and Department of Physics of the University of Naples "Federico II") [10];

- fluorescence optical sensors, the SecurEau project developed the pre-industrialized sensor KaptaTM 3000 OT3 (SecurEau project);

- optical spectroscopic sensor (IREA-CNR) [11];

- chemical sensors based on carbon nanotubes (Proteus project).

All these OMSs measure different parameters discussed in the following section of the paper.

The technical literature and the company brochures about on-line monitoring sensors are often confuse, and, do not describe sufficiently the technologies adopted. Indeed, a relevant classification of online water quality monitoring system was provided by [12], in which the authors proposed a list of parameters, measured by Real-Time monitoring sensors (RTS) (without the use of chemical reagent) available on the market. This classification was revised by Ctrl+SWAN members in a following work [13] published in 2015, indicating which sensors, defined OMS and not RTS, based also on the use of chemical reagents were already available on the market, which were in development phase and which were already in the research phase.

During the last two years, Ctrl+SWAN membership has grown considerably collecting new companies, water utilities, universities and research centers of proven experience in the water sector. Therefore, the aim of this paper, with the help of the AG members, is essentially to update the list of parameters, measured with innovative OMS, and novel technologies in development not already on the market to show to scientific and technical community the improvements in this crucial technology for WS. 


\section{Water Quality Sensors and Data in Water Systems}

Water monitoring is a huge challenge and online sensor monitoring satisfy the growing need for effective solutions to control key parameters for everyday life (e.g. drinkable water), for economies which depend on water (e.g. water utility, blue economy, etc) and for sustainable environment (e.g. use of natural resources and climate change).

Therefore, there is an emerging need for sensitive, selective and field portable or autonomous devices for real-time or near real-time water quality monitoring, in order to provide more valuable information for stakeholders. A great opportunity to obtain real-time information about water quality, quantity, usage and energy associated with water usage is given by the adoption of smart water devices, such as OMS. Focusing on water quality, technologies integrating into a Smart Water System can range from overall quality measurements (such as those made by physicochemical or non-specific sensor systems [14]) to analytical measurements of specific chemical and biological parameters of the water.

On one side, several advantages can be achieved by using innovative online sensors, in the improvement of maintenance and management of Water Systems, while on the other side water monitoring through OMS involves also drawback. In fact, sensors are still too expensive and potential of data are under exploited. Therefore, emerge a need for R\&D in reducing the costs and plugging sensor into the Digital Single Market for Water Services as highlighted by the recent report of the ICT4Water cluster.

Furthermore, as reported in [8], OMS still do not fit all practical utilities request and water quality regulations so their integration in early warning systems are still in development, an example is reported in [9]. On this side, the integration of OMS into smart water networks is gaining importance with the advancements in the ICT field. Depending on the communication technologies available and the parameters to be monitored, different applications including the data management functions, data analysis and alert system based on the monitored parameters, were developed as reported in [15]. A simple experiment involving AG members is reported in [18].

Consequently, the use of online sensor technology in Water Systems can provide a huge amount of water quality data in space and time - that can be merged in a peculiar new category of Big Data, naming Water Quality Data (WQD) - that can be used for some possible applications [16]. In fact, these data will allow to develop empirical and deterministic models for prediction, forecasting and early warning.

The connection of sensors and data acquisition systems allows to monitor and transmit data for analysis and action, evidently, as reported in [17], rough Water Quality Data not properly treated and analyzed are not useful for water utilities applications, while WQD, treated with innovative data analysis techniques, can be used for operational or regulatory purposes, as:

- improve the quality of services and the customer service (e.g. optimization of treatment processes control, nearly real-time identification of possible contaminants, etc.);

- increase end users' awareness (e.g. characteristic of water, environment sanitation, etc.);

- affect end user behavioral change (e.g. hygiene, use of tap water for drinking purpose, etc.).

\section{Innovation in OMS WQ Parameters and Technologies}

Starting from the classification of online water quality monitoring system provided by [12], and the definition of three levels of importance for water quality parameters: Low, Medium and High, CTRL+SWAN members reviewed the classification, as reported in [13], with reference to OMS 
available on the market and on development, by adding parameters that requires the use of chemical reagents. This choice is related to the diffusion of automatic commercial device based on chemical reagents, which are characterized by a short response time and so allow on-line measurements.

Given the development of technologies and the R\&D activity of some AG members on the developing of innovative OMS, in order to measure on-line many water quality parameters, it is possible to update the table, reported in [13].

Specifically, the Table 1 shows the list of parameters revised by parameters for which online sensor are now on the market (bold characters) or in an $\mathrm{R} \& \mathrm{D} /$ development phase (bold characters with asterisk). Water quality parameters, in the Table 1, are also updated in respect of their level of importance (bold characters in braket) moving from a level to another one compared with the previous Table [13].

\begin{tabular}{|c|c|c|c|}
\hline \multicolumn{4}{|c|}{ Importance of online measurement of a Water Quality parameter } \\
\hline $\begin{array}{l}\text { Availab } \\
\text { ility on the } \\
\text { market }\end{array}$ & LOW & MEDIUM & $\mathrm{HIGH}$ \\
\hline $\begin{array}{l}\text { No online } \\
\text { sensors } \\
\text { available }\end{array}$ & $\begin{array}{l}\text { Aldehydes, anionic surfactants, antimony, } \\
\text { barium, beryllium, brominated DBP, , } \\
\text { chlorate, chlorite, dichloramine, Drug } \\
\text { metabolites, formaldehyde, glyphosate, } \\
\text { haloacetic acids, heterotrophic plate counts } \\
\text { (HPC) bacteria, malathion, marine algal } \\
\text { Toxins*, molybdenum, parasites, bacteria* } \\
\text { and viruses, pesticides*, phosphate } \\
\text { inhibitors, selenium, and } \\
\text { sulphonammides, taste and odour, } \\
\text { trihalomethanes, vanadium, viable bacteria }\end{array}$ & $\begin{array}{l}\text { heavy metals*, } \\
(\text { cadmium*), } \\
\text { (mercury) }\end{array}$ & $\begin{array}{l}(\text { E. coli*), } \\
\left.\text { coliform }^{*}\right)\end{array}$ \\
\hline $\begin{array}{l}\text { Can be } \\
\text { indirectly } \\
\text { estimated } \\
\text { using } \\
\text { available } \\
\text { online } \\
\text { sensors }\end{array}$ & $\begin{array}{l}\text { Assimilable organic carbon (AOC), ozone, } \\
\text { radioactivity, stability, total suspended } \\
\text { solids, uranium, trihalomethane } \\
\text { formation potential }\end{array}$ & Lead* $^{*}$ & - \\
\hline $\begin{array}{l}\text { Online } \\
\text { sensors } \\
\text { available }\end{array}$ & $\begin{array}{l}\text { Algal pigments, (arsenic), } \begin{array}{l}\text { (boron), } \\
\text { (chemical oxygen demand), chloramine, }\end{array} \\
\text { chlorine, (cobalt), (corrosion inhibitors), } \\
\text { dioxide, (dissolved organic carbon), flow, } \\
\text { fluorescence, (hydrogen sulphide), level } \\
\text { sensors, (manganese), multi-angle light } \\
\text { scattering, (magnesium), multi-spectrum } \\
\text { absorption, (nitrogen organic), pressure, } \\
\text { (potassium), (silicon), (silicate), (sodium), } \\
\text { streaming current, total chlorine, total } \\
\text { dissolved solids, (toxicity), ultraviolet } 254 \\
\text { nm absorption (SAC 254), UV visible } \\
\text { spectra, volatile organic carbon, total } \\
\text { trihalomethanes }\end{array}$ & $\begin{array}{l}\text { (Alkalinity), } \\
\text { (aluminium), } \\
\text { bacterial count, } \\
\text { (calcium), (chromium } \\
6+\text { ), chromium } \\
\text { speciation*, (copper), } \\
\text { fluoride, (hardness), } \\
\text { (iron), , (nickel), } \\
\text { (nitrite), particle } \\
\text { count, , (sulphate) } \\
\begin{array}{l}\text { temperature, total } \\
\text { residual chlorine, } \\
\text { (zinc) }\end{array}\end{array}$ & $\begin{array}{l}\text { Ammonia, (chloride), } \\
\text { colour, conductivity, } \\
\text { dissolved oxygen, free } \\
\text { residual chlorine, } \\
\text { COD, (nitrate), } \\
\text { (orthophosphate), } \\
\text { (phosphorus), } \\
\text { oxidation reduction } \\
\text { potential, } \\
\text { turbidity, } \quad \text { (total } \\
\text { cyanide), (total } \\
\text { organic carbon) }\end{array}$ \\
\hline
\end{tabular}

Table 1: Updated list of parameters for on-line measurement

The effort of each AG member was first to update Table 1 and, then, to provide a contribution on the possibility of on-line monitoring of some very important biological parameters (as, i.e. Pesticide, 
Bacteria Protozoa or Virus) or chemical parameters (Lead, Alkalinity, Aluminum, Ammonia, Ammonium, Anionic Surfactans, Arsenic, Cadmium, Chloride, Chromium 6+, Copper, Fluoride, Heavy Metals, Hydrocarbons, Iron, Lead, Manganese, Mercury, Nitrate, Nitrites, Organic Compounds, Orthophosphates, Phosphate, Phosphates Silicates, Cyanides, Total Nitrogen, Total Phosphorus Volatile Phenols, disinfection by-products, etc.).

In fact, based on their Knowledge expertise, each AG members provided some innovative current and potential OMS, based on different methods/techniques that, integrated in a water network, can contribute to improve management, protection, awareness, early warning, etc... The proposed OMSs are summarized in the following Table 2, which reports a synthetic description of the parameters targeted by AG members. This table represents an update of what was reported in [13] (new parameters are in bold characters). The updated list includes: i) on-line measurement techniques already available on the market; ii) methods and techniques under pre-market development; iii) methods and techniques at research level.

\begin{tabular}{|c|c|c|c|c|c|}
\hline $\begin{array}{c}\text { On-line measured } \\
\text { parameters }\end{array}$ & $\begin{array}{l}\text { AG members } \\
\text { and partners }\end{array}$ & Methods/Techniques & Research & Development & $\begin{array}{l}\text { On } \\
\text { mar } \\
\text { ket }\end{array}$ \\
\hline Pesticide & $\begin{array}{l}\text { Novaetech srl, } \\
\text { Department of } \\
\text { Physics of the } \\
\text { University of } \\
\text { Naples } \\
\end{array}$ & $\begin{array}{l}\text { Quartz-Crystal } \\
\text { Microbalance with } \\
\text { antibodies }\end{array}$ & & $\mathrm{X}$ & \\
\hline Bacteria & $\begin{array}{l}\text { Novaetech srl, } \\
\text { Department of } \\
\text { Physics of the } \\
\text { University of } \\
\text { Naples }\end{array}$ & $\begin{array}{l}\text { Quartz-Crystal } \\
\text { Microbalance with } \\
\text { antibodies }\end{array}$ & $X$ & & \\
\hline $\begin{array}{l}\text { Alkalinity, ammonia, } \\
\text { chlorine dioxide, } \\
\text { chloride, chloramine, } \\
\text { corrosion inhibitors, } \\
\text { dissolved oxygen, } \\
\text { hardness, hydrocarbons, } \\
\text { fluoride, nitrate, nitrite, } \\
\text { orthophosphates, ozone, } \\
\text { phosphate, sodium, } \\
\text { silicate, sulphide, total } \\
\text { suspended solids, total } \\
\text { organic carbon, total/free } \\
\text { residual chlorine, total } \\
\text { cyanide, turbidity, } \\
\text { ultraviolet } 254 \text { nm } \\
\text { absorption }\end{array}$ & $\begin{array}{l}\mathrm{HACH} \\
\text { LANGE }\end{array}$ & $\begin{array}{l}\text { Amperometric, digital, } \\
\text { optical probes, ion- } \\
\text { selective electrode } \\
\text { (ISE) technology, } \\
\text { photometric analyzers, } \\
\text { UV absorption, electro } \\
\text { chemical sensors, } \\
\text { radical advanced } \\
\text { oxidation, light } \\
\text { scattering analytics, }\end{array}$ & & & $X$ \\
\hline $\begin{array}{l}\text { Alkalinity, aluminium } \\
\text { dissolved and total, } \\
\text { ammonia, arsenic diss. } \\
\text { and total, BOD; } \\
\text { calcium, chloride, } \\
\text { chlorine (total and } \\
\text { free), chromium 6+ and } \\
\text { total, COD, color, } \\
\text { copper diss. and total, } \\
\text { ethylene gycol, fluoride, }\end{array}$ & $\begin{array}{l}\text { SYSTEA } \\
\text { SpA }\end{array}$ & $\begin{array}{l}\text { Wet-chemistry } \\
\text { automated spectro- } \\
\text { photometric methods } \\
\text { fluorimetry, Ion- } \\
\text { Selective Electrode } \\
\text { (ISE), InfraRed light } \\
\text { scattering, UV- } \\
\text { absorption }\end{array}$ & & & $\mathbf{X}$ \\
\hline
\end{tabular}




\begin{tabular}{|c|c|c|c|c|c|}
\hline $\begin{array}{l}\text { hardness, hydrazine, } \\
\text { iron diss. and total, } \\
\text { manganese diss. and } \\
\text { total, } \\
\text { monochlorammine, } \\
\text { nickel diss. and total, } \\
\text { nitrate, nitrite, } \\
\text { orthophosphate, } \\
\text { silicates, sucrose, } \\
\text { sulphate, sulphide, } \\
\text { volatile phenols, silver } \\
\text { total, total cyanides, } \\
\text { TOC, total nitrogen, } \\
\text { total phosphorus, total } \\
\text { suspended solids (TSS), } \\
\text { ultraviolet } 254 \text { nm } \\
\text { absorption (SAC), zinc } \\
\text { diss.and total }\end{array}$ & & & & & \\
\hline Acute toxicity & $\begin{array}{l}\text { SYSTEA } \\
\text { SpA }\end{array}$ & $\begin{array}{l}\text { Bacteria luminescence } \\
\text { optical detection }\end{array}$ & & & $\mathbf{X}$ \\
\hline $\begin{array}{l}\text { Lead, admium, } \\
\text { mercury }\end{array}$ & $\begin{array}{l}\text { SYSTEA } \\
\text { SpA }\end{array}$ & $\begin{array}{l}\text { Wet chemistry } \\
\text { automated } \\
\text { fluorimetry }\end{array}$ & & $\mathbf{X}$ & \\
\hline $\begin{array}{l}\text { Anionic surfactans, } \\
\text { sulphonamides, marine } \\
\text { algal toxins (saxitoxin, } \\
\text { domoic acid, okadaic } \\
\text { acid) }\end{array}$ & $\begin{array}{l}\text { SYSTEA } \\
\text { SpA }\end{array}$ & $\begin{array}{l}\text { Wet-chemistry } \\
\text { automated } \\
\text { spectrophotometric } \\
\text { method }\end{array}$ & & $\mathbf{X}$ & \\
\hline $\begin{array}{l}\text { E.coli and total } \\
\text { coliforms }\end{array}$ & $\begin{array}{l}\text { SYSTEA } \\
\text { SpA }\end{array}$ & $\begin{array}{l}\text { MPN automated } \\
\text { quantification by } \\
\text { fluorescence \& color } \\
\text { absorption }\end{array}$ & & $\mathbf{X}$ & \\
\hline Heavy metals & $\begin{array}{c}\text { CNR- } \\
\text { IBF+ISTI }\end{array}$ & $\begin{array}{l}\text { Nanofiber materials, } \\
\text { based on } \\
\text { electrochemical } \\
\text { techniques. }\end{array}$ & $\mathbf{X}$ & & \\
\hline $\begin{array}{l}\text { Hydrocarbons, nitrates, } \\
\text { organic compounds, } \\
\text { phosphates }\end{array}$ & IREA-CNR & $\begin{array}{l}\text { Optofluidic jet } \\
\text { waveguide }\end{array}$ & $\mathrm{X}$ & & \\
\hline $\begin{array}{l}\text { Ammonia, chlorides, } \\
\text { nitrates }\end{array}$ & IREA-CNR & Microwave resonator & $\mathrm{X}$ & & \\
\hline $\begin{array}{l}\text { Ammonium, E. coli, } \\
\text { heavy metals, nitrites and } \\
\text { nitrates, phosphate, total } \\
\text { coliform }\end{array}$ & Edgelab srl & Electrochemical & $\mathrm{X}$ & & \\
\hline Cadmium, Lead & Promete srl & Bio-based electrodes & $\mathrm{X}$ & & \\
\hline$e$-coli & DCU & $\begin{array}{l}\text { Enzyme based } \\
\text { biosensor }\end{array}$ & & $\mathbf{X}$ & \\
\hline $\begin{array}{l}\text { Water Quality monitor } \\
\text { (Optical clarity) }\end{array}$ & DCU & Optical sensor & & $\mathbf{X}$ & \\
\hline Marine algal toxin & DCU & $\begin{array}{l}\text { Antibody-based } \\
\text { fluorescence biosensor }\end{array}$ & $\mathbf{X}$ & & \\
\hline
\end{tabular}




\begin{tabular}{|c|c|c|c|c|c|}
\hline Phosphate & DCU & $\begin{array}{l}\text { Microfluidics - blue } \\
\text { method }\end{array}$ & $\mathbf{X}$ & & \\
\hline Chromium speciation & DCU & $\begin{array}{l}\text { Microfluidics - on } \\
\text { chip heating and } \\
\text { separation. }\end{array}$ & $\mathbf{x}$ & & \\
\hline $\begin{array}{l}\text { PH, Conductivity, } \\
\text { Pressure, temp, } \\
\text { Chlorine, chloride }\end{array}$ & $\begin{array}{l}\text { PROTEUS } \\
\text { project }\end{array}$ & $\begin{array}{l}\text { MEMS + Carbon } \\
\text { Nano tubes }\end{array}$ & $\mathbf{X}$ & $\mathbf{X}$ & \\
\hline $\begin{array}{l}\text { Microbiological total } \\
\text { activity (viable } \\
\text { bacteria) }\end{array}$ & $\begin{array}{l}\text { MicroLAN } \\
\text { (validated by } \\
\text { Cetaqua) }\end{array}$ & $\begin{array}{l}\text { Enzyme activity } \\
\text { (alkaline phosphatase) } \\
\text { by fluorescence }\end{array}$ & & & $\mathbf{X}$ \\
\hline $\begin{array}{l}\text { Microbial count, } \\
\text { particle count }\end{array}$ & $\begin{array}{c}\text { Mettler } \\
\text { Toledo } \\
\text { (validated by } \\
\text { Cetaqua) } \\
\end{array}$ & $\begin{array}{l}\text { Light scattering + } \\
\text { intrinsic fluorescence } \\
\text { detection }\end{array}$ & & & $\mathbf{X}$ \\
\hline $\begin{array}{l}\text { Bacterial count, particle } \\
\text { count }\end{array}$ & $\begin{array}{l}\text { Grundfos } \\
\text { (validated by } \\
\text { Cetaqua) }\end{array}$ & 3D microscopy & & & $\mathbf{X}$ \\
\hline $\begin{array}{l}\text { Colour (+ in pipe), } \\
\text { conductivity, nitrate, } \\
\text { total organic carbon, } \\
\text { temperature (+ in pipe), } \\
\text { total/free residual } \\
\text { chlorine, turbidity (+ in } \\
\text { pipe), ultraviolet } 254 \\
\text { nm absorption (+ in } \\
\text { pipe), UV-visible } \\
\text { spectra and } \\
\text { contamination alarm }\end{array}$ & $\begin{array}{l}\text { s::can } \\
\text { (validated by } \\
\text { Cetaqua) }\end{array}$ & $\begin{array}{l}\text { Amperometry } \\
\text { (membrane), electro- } \\
\text { chemical sensor, } \\
\text { optical probes, UV-vis } \\
\text { spectrometry }\end{array}$ & & & $\mathbf{X}$ \\
\hline
\end{tabular}

\section{Conclusion}

Monitoring is becoming one of the main topics of the water sector and there is a growing demand to control key parameters of Water Systems. Enhancement in water quality depends on the availability of precise and fast information, therefore the integration of innovative OMS in the WSs can improve their management and their protection, transforming the traditional water networks in modern SWANs. Amongst many challenges, an emerging need for innovative low-cost solutions, providing local intelligence (for prediction purposes) while connected to the SWANs, is requested. The challenge is to promote a smart water management, to raise users' awareness and protection, to optimize the use of water resource and to move up to a sustainable economy.

The activities of AG Ctrl+SWAN is to study, develop, disseminate and imagine the innovative applications of OMS in water networks to improve water management and protection. Some members are already ready to put on the market their smart devices, while others are working on the development and testing of innovative sensor. The continuous activity of research, development and dissemination of AG members can represent a point of reference in the field of OMS and can contribute enhance the implementation of smart monitoring systems in the water sectors and the development of integrated tools for a smart water system management. 


\section{References}

[1] D.Washburn, U. Sindhu, S. Balaouras, R.A. Dines, N.M. Hayes, L.E. Nelson, Helping CIOs Understand "Smart City" Initiatives: Defining the Smart City, Its Drivers, and the Role of the CIO, Forrester Research Inc., Cambridge, 2010.

[2] A. Di Nardo, M. Di Natale, G.F. Santonastaso, S. Venticinque, An automated tool for smart water network partitioning, Water Resources Management, 27(13) (2013a) 4493-4508.

[3] C.S. Laspidou, ICT and stakeholder participation for improved urban water management in the cities of the future, Water Utility Journal 8 (2014) 79-85.

[4] D.Savic, L.Vamvakeridou-Lyroudia, Z. Kapelan, Smart Meters, Smart Water, Smart Societies: The iWIDGET Project, Procedia Engineering 89 (2014) 1105-1112.

[5] USEPA (United States Environmental Protection Agency), Technologies and techniques for early warning systems to monitor and evaluate drinking water quality: a state-of-the-art review, United States Environmental Protection Agency, USA, 2005a.

[6] A. Di Nardo, M. Di Natale, D. Musmarra, G.F. Santonastaso, V. Tzatchkov, V.H. AlcocerYamanaka, Dual-use value of network partitioning for water system management and protection from malicious contamination, Journal of Hydroinformatics 17(3) (2014).

[7] J. Raich, CETaqua, Agbar Group, Review of sensors to monitor water quality, Report EUR 26325 EN, 2013.

[8] B. van der Gaag, J. Volz, Real-time on-line monitoring of contaminants in water Developing a research strategy from utility experiences and needs, Kiwa Water Research, 2008.

[9] B. R. de Graaf et al., Implementation of an innovative sensor technology for effective online water quality monitoring in the distribution network, Water Practice \& Technology 7(4) (2012) 1-12.

[10] B. DellaVentura, M.Iannaccone, R.Funari1, M.P.Ciamarra, C.Altucci1, R.Capparelli, S.Roperto, R.Velotta, Effective antibodies immobilization and functionalized nanoparticles in a quartz-crystal microbalance-based immunosensor for the detection of parathion, PLoS ONE 12(2) (2017).

[11] G. Persichetti, R.Bernini “ Water monitoring by optofluidic Raman spectroscopy for in situ applications" Talanta 155 (2016) 145-152.

[12] A. Lee, A. Francisque, H. Najjaran, M.J. Rodriguez, M. Hoorfar, S.A. Imran, R. Sadiq, Online monitoring of drinking water quality in a distribution network: a selection procedure for suitable water quality parameters and sensor devices, Int J Syst Assur Eng Manag 3(4) (2012) 323-337.

[13] A. Di Nardo et al., New Perspectives for Smart Water Network monitoring, partitioning and protection with innovative On-line Measuring Sensors, Procceding of IAHR 2015, 2015.

[14] Di Natale C., Dini F. and Scozzari A., Non-conventional Electrochemical and Optical Sensor Systems. In: A. Scozzari and E. Dotsika (eds.), Threats to the Quality of Groundwater Resources: Prevention and Control, Springer-Verlag, Berlin Heidelberg (2016), pp. 279-31.

[15] S. Geetha, S. Gouthami, Internet of things enabled real time water quality monitoring system, Smart Water International Journal for @qua-Smart ICT for Water 2:1, Springer, 2017.

[16] Stefan Reis et al., Integrating modelling and smart sensors for environmental and human health, Environmental Modelling \& Software 74 (2015) 238-246.

[17] A. Cominola, M. Giuliani, A. Castelletti, D.E. Rosenberg, A.M. Abdallah, Implications of data sampling resolution on water use simulation, end-use disaggregation, and demand management, Environmental Modelling and Software 102 (2017) 199-212.

[18] Scozzari A., Brozzo G. Making use of continuous measurements for change detection purposes: an application to water distribution networks, IEEE Instrumentation and Measurement Technology Conference (I2MTC), IEEE International (USA), Turin (2017), pp. 6. 